\section{The "No Dirty Gold" campaign: what economists can learn from and contribute to corporate campaigns}

John Tepper Marlin

A cademic economists have had a great impact on actors in financial marketplaces: the Black-Scholes options-pricing model for instance spawned an industry on Wall Street. But economists have had trouble in recent years affecting issues of war and peace, even though since Adam Smith many economists have stressed the destructive and wasteful nature of wars. Recent United States military decisions appear to have been made either independently of economic analysis or with such analysis buttressing plans to invade countries with valuable natural resources.

Economists can increase their policy impact by studying successful NGO campaigns against corporate actors.

Economists had more input during the Cold War, when issues relating to missiles and missile defense were openly debated. The enemy was clear and the issue was how best to respond to threats. But now U.S. military expenditure is growing to wage wars in questionable places against amorphous foes. The rationale given for invading Iraq was as a response to the terror attack of 11 September 2001, perpetrators of which were largely Saudi nationals - evidence of Iraqi involvement is still hard to find.

My thesis is that economists can have more impact by studying NGOs successfully working on corporate campaigns for higher environmental or labor standards. The “No Dirty Gold” (NDG) campaign may offer a model for economists.

The “No Dirty Gold” campaign and the jewelry industry response

The "No Dirty Gold" campaign is jointly sponsored by OxfamAmerica and Earthworks. ${ }^{1}$ The campaign began in 2004 and showed renewed life in the first half of 2006. The NDG campaign targets are clear and visible: corporations with known brand names. The army on the NDG side is made up of jewelry consumers. By early 2006, NDG had accumulated 50,000 pledges from consumers forswearing purchase of gold jewelry from any retailers who do not subscribe to the NDG "Golden Rules" relating to the source of their gold.

In February 2006, major jewelry retailers companies signed on to the Golden Rules. The first to sign was Tiffany \& Co. The others were Zale, the Signet Group (parent of Sterling and Kay Jewelers), Helzberg Diamonds, Fortunoff, Cartier, Piaget, and Van Cleef \& Arpels. These represented, in February 2006, a market share of 14 percent of U.S. jewelry sales, mostly on the luxury end of the retail jewelry marketplace and in middle-market sales in shopping malls. By May 2006, three more retailers had joined, Turning Point, Fred Meyer Jewelers, and Michaels Jewelers.

NDG has succeeded in bringing on board virtually all of the upscale brand names in the jewelry business and, according to the NDG campaign in June 2006, several other large retailers are engaged in a promising dialog with NDG: WalMart, QVC, and Whitehall. Non-signing jewelry-selling holdouts that are not engaged in such a dialog are: (1) mass-market generic vendors J. C. Penney and Sears/KMart, and (2) Rolex and (surprisingly, given the company's potential vulnerability to a student campaign during the coming year) Jostens, which supplies jewelry to school and college students.

Signatory retailers have made it clear they expect to use their influence with mining companies and that (1) they feel morally obliged to respond, (2) as businesses they have a pragmatic need to protect their reputations, and (3) the extent to which they will be effective depended on NDG keeping up the pressure from jewelry consumers. Michael J. Kowalski, Tiffany’s Chairman and CEO, said he understands that the heavy lifting was still to be done: "What does indeed constitute a responsible mining operation? Who's there at the moment, and how do we get to where we need to be? The critical next step is reaching a substantive agreement on those questions."2

The practical outcome of corporate support for the NDG campaign is the Council for Responsible Jewellery Practices (CRJP), ${ }^{3}$ which as of April 2006 had 43 members including the eight previously cited retailers, seven industry associations, six gold/diamond mines, and 22 refining, manufacturing, trading, and wholesaling organizations. The CRJP was created to "promote responsible practices relating to business ethics, social, human rights and environmental performance throughout the diamond and gold jewellery supply chain from mine to retail."

The CRJP has been funded by its members at a level adequate to hire two competent staff members from the NGO community. A Code of Practices has been created specifying the expectations for gold mining practices (both environmental and worker-related), and the CRJP is on track to having a significant effect. The specific social and environmental standards that CRJP decides that gold producers should work toward and eventually implement have not yet been developed. The quality of these standards will determine whether or not they address the concerns of the NDG campaign. 
The heart of the NDG campaign: pulling the supply chain

It is too early to break out the champagne and announce that the NDG campaign has achieved its environment and labor goals. It is an open question how carefully the CRJP Code will be audited and enforced. But the jewelry industry has moved remarkably quickly to respond to issues that have been raised by NGOs and explicitly credits the NDG campaign as its motivating driver.

Can economic concepts help explain why the NDG campaign took root so quickly? Can this analysis in turn provide insights to economists to help them address broader issues of influencing issues of war and peace?

Prior experience in the industry

Every campaign is path-dependent, following in the footsteps of campaigns that have come before. Jewelry retailers were the targets starting on Valentine's Day 2001 of a previous campaign sponsored by Physicians for Human Rights, ${ }^{4}$ Oxfam America, and 71 other NGOs against "blood” or "conflict” diamonds being used to finance civil wars in Sierra Leone and Angola. The clean diamonds campaign led to the Kimberley Process for identifying such diamonds, and this was effective in breaking links between the such diamonds and major jewelry retailers. ${ }^{5}$ Unintended outcomes include an increase in the oligopolistic power of large diamond merchants operating in Africa and a shift of diamond-buying out of Africa to other continents. Retailers' response to this issue may also have been relatively easy, since conflict diamonds involve only about 4 percent (according to an industry spokesman) of diamonds coming on the market each year. Having a prior victory with this constituency provided some momentum for the NDG campaign, which raises more widely prevalent issues with the industry.

The clout of buying power down the supply chain

Wal-Mart has become the world's biggest company by using its buying power to bring down costs to the consumer. This demonstrates the influence that buyers can bring to bear on the way that goods and services are provided. The fact that wages and benefits for most of its own workers has been big part of Wal-Mart's costcutting is a reason for a new campaign targeted against it. It remains to be seen how responsive consumers will be to a campaign against a company that has swept the field as the lowest-cost retailer, but management in Bentonville has responded by recently switching PR agencies, talking with NGOs, and launching several new environmental initiatives. If NDG activists are able to get Wal-Mart's attention, they should find it a lot easier to get the attention of less price-competitive retailers.
The vulnerability of brands

A consumer brand is more vulnerable to buying power than a generic product. It costs money to advertise the brand, and this cost must be recouped in the price. For example, in Europe, where the banana industry is protected, brands make a big difference; in the United States the brand of banana matters much less. Europeans will choose one brand of banana over another based on perceived environmental differences, and Chiquita bananas are preferred. Therefore Chiquita is attaching its environmentally conscious frog - courtesy of a Rainforest Alliance certification to its labels in Europe, but not in the United States, where bananas are more of a generic commodity. ${ }^{6}$ One can say that European environmental consciousness is a main driver of Chiquita's compliance with environmental standards on its farms and on the farms of its suppliers. The jewelry industry is composed of high-cost, luxury brands that have invested heavily in their reputations. With the price of gold substantially higher in 2006 than 2005, gold jewelry is even more of a luxury. Jewelry retailers and their suppliers cannot afford to take chances with being tarred by an activist campaign.

The commitment of "Bitten Brands"

Once bitten, twice shy. When a brand has been "bitten” by consumer activists, the brand's managers often take up the cause with the zeal of a new convert. Gap Inc. was "bitten" by anti-sweatshop activists who paraded naked around the company's headquarters in San Francisco to show that they would rather wear nothing at all than clothes made in a sweatshop. The distinguished family that started Gap Inc. became anguished and embarked on a uniquely aggressive anti-sweatshop initiative. $^{7}$ The company was an early leader in seeking compliance with the SA 8000 labor standard and in issuing a detailed report on the progress toward compliance of its suppliers. ${ }^{8}$ As of mid-2006, the corporate responsibility function at Gap Inc. was headed by a Senior Vice President with a staff under his direction of more than 90 people. In the jewelry industry, the leading brands were given enough taste of small bites by the conflict diamonds campaign that they do not wish to risk a big bite from the NDG campaign. As a New York City-based jewelry company spokesman said in the spring of 2006: "We have seen the economic impact on the fur industry of animal activists spray-painting wearers of furs. We don't want to risk this kind of thing happening to us.”

Industrial structure and countervailing power

To borrow a term from the late, great John Kenneth Galbraith, in some industries the targets of activist campaigns have "countervailing power" to exercise in the 
face of intransigent local operators. This power is more easily exercised when a powerful supplier must face competition from elsewhere in the world. The extractive industries - mining and drilling - are the most vivid examples because they require large investments, and the corporate investors are tied to the land in ways that banana producers are not (banana growing needs sunshine and water as well as land, but many parts of the world meet these requirements). Mining and oil drilling differ in their corporate structures. Although wildcat drillers continue to survive, much of global oil industry is vertically integrated. The ExxonMobil that sells us oil at a local gas station is the same ExxonMobil that operates oil wells and refinery operations. In contrast, in the case of gold mining, retailers and mines are largely separate activities. Freeport McMoRan and Newmont Mining dig for minerals mostly in remote areas of Indonesia, Africa, and Latin America with no stores on Fifth Avenue or Main Street. Conversely, Tiffany \& Co. and Cartier do not operate any gold mines. As has been shown in the apparel, footwear, and toy industries, consumer activists are best able to put pressure on retailers, and to use them to change the ways of suppliers.

\section{Special reasons for the success of the NDG campaign}

\section{Easily articulated and visualized issues}

The conflict diamonds issue was easily visualized as having victims among combatants in civil wars, but the connection to the consumer was harder to articulate because of the circuitous supply chain. The environmental and social problems related to gold mining are easy to describe and to show with photographs and videos. NDG activists are making prominent use of the statistic that 20 tons of mining waste are required to produce one gold ring.

The backdrop of higher gold prices

Another economic factor weighing on the minds of the jewelry industry is that gold as a commodity is a focus of speculators. The price of gold was US\$620/ounce in early June 2006, a hefty increase over the US $\$ 425$ price a year earlier. ${ }^{9}$ The continuing twin U.S. trade and budget deficits and Fed Chairman Ben Bernanke's expressed worries about core inflation have put pressure on the dollar and that is associated with speculative and panicky buying of gold, especially in Asian countries with large dollar inflows like India and China. What this means for the gold jewelry industry is that it must raise the prices of its products, creating sticker shock for customers. Other precious metals, in their roles both as complements to and substitutes for gold, are also affected. In a climate of rising prices, the NDG campaign could provide a deontological rationale for consumers to avoid buying gold jewelry (although the NDG has explicitly not called for such a boycott) when the real reason might be that the jewelry seems overpriced by historical standards.

The synergy of corporate campaigns

The NDG campaign supports, and is supported by, parallel corporate campaigns. For example, New Orleans-based Freeport McMoRan is defending US\$35 million in payments by its Indonesian mine to government military personnel for security purposes. ${ }^{10}$ This is the subject of a long-running proxy campaign against Freeport by the New York City Comptroller's Office on behalf of New York City employee pension funds. ${ }^{11}$ Rio Tinto is a 40 percent shareholder in Freeport and has agreed to join the CRJP. ${ }^{12}$ For Rio Tinto to remain in compliance with the CRJP draft code of practices Business Ethics Code 3.1.3, it must address the issue of bribery and gifts: "In all business transactions that are carried out by them, or on their behalf, by business associates or contractors, members will prohibit bribery in any form. They will not offer, accept or countenance any payments, gifts in kind, hospitality, expenses or promises as such that may compromise the principles of fair competition or constitute an attempt to obtain or retain business for or with, or direct business to, any person; to influence the course of the business or governmental decision-making process.”

Overall: why the NDG campaign is working

The NDG campaign has linked a real problem - the labor and environmental problems of gold mines - with an industry group that is vulnerable to a consumer campaign. It is operating in a market environment in which the gold jewelry industry must raise prices and has reason to fear a consumer backlash against these prices. It is led by two NGOs, Oxfam America and Earthworks, that know how to reach consumers. The campaign has shown flashes of brilliance and savvy (for example, on www.responsiblejewellery.org one gets to the NDG campaign with an attractive home page and a place to sign the petition). ${ }^{13}$ It is supported by parallel campaigns. This sophisticated campaign offers the jewelry industry carrots while the sticks are in plain sight.

\section{What economists can learn from the NDG campaign}

In their work environment, economists with a policy orientation typically defer to 
politicians and senior executives. Economists apply their tools where they can and come up with options for the politicians and executives for whom they work. (Some cross the line and become these politicians and executives.) The strength of NGOs is that they can continue to press their arguments in the public arena regardless of the official positions of elected officials and corporate executives, so long as the NGOs have a base of support.

Staff and academic economists tend to be agnostic when issues are posed politically in ways that do not lend themselves to quantification. The invasion of Iraq was predicated on Saddam Hussein possessing Weapons of Mass Destruction, a claim later shown to be unsubstantiated. On the whole, economists had little to say on that topic. ${ }^{14}$

It would be different if the issue were raised in a way that economists are used to answering. If the U.S. President had asked: "How much money should the United States be prepared to spend on a war in Iraq?” then economists could bring out their tools, such as analysis of costs, of the kind ably done by economics Nobel-Laureate Joseph Stiglitz and others. Part of the problem with the Iraq war is that it is being paid for with a series of debt-financed supplemental appropriations averaging about US $\$ 100$ billion per year (including continuing costs in Afghanistan) that is not subject to the normal congressional scrutiny. Only the routine Pentagon budget set to reach US\$440 in FY 2007 is subject to scrutiny.

Economists seeking a peace dividend might find the NDG campaign useful because polls show growing questions about the war in Iraq:

$<$ Is it contributing to peace and security?

$<$ How long should the United States remain in the midst of what has become a civil war?

$<$ Are the human and public costs of the war justified by the benefits?

A recent article by leaders of MIT's Security Studies Program is frank: "The dirty secret of American security politics is that we are safe.” To fill the vacuum of a credible opponent on the world scene, the architects of current U.S. military expenditure must rely on an undefined enemy that the MIT professors call "You Never Know." They argue that "You Never Knowism is the guiding ethos of U.S. national security. National security planning documents ... claim that the simple Soviet threat has been replaced by more various and irrational ones ... with no particular foe in mind." 15

Most corporations have a natural interest in peacekeeping and peacemaking: it's better for business.
Most corporations have a natural interest in peacekeeping and peacemaking. Wars interfere with trade and tourism. Business executives are like everyone else in preferring not to be shot at while they are going about their work, a fact amply illustrated by the flight of corporations from New York City when crime seemed to be out of control.

More important, corporate executive are aware of opportunity costs. The money being spent in Iraq could pay for a universal health care program, alleviating the heavy burden on corporations of employee health care costs that has contributed to the decline of the U.S. automotive industry and other manufacturing. Or it could be spent on improving public education, raising the skill levels of the next generation of American workers.

The likely exceptions to the general rule that business prefers peace are the following kinds of companies:

$<$ Companies that sell arms to the United States government, what President Eisenhower called the "military-industrial complex," or to other countries.

$<$ Companies that contract for rebuilding areas that have been destroyed.

$<$ Companies with a heavy investment in natural resources that is threatened by political developments in the country where the resources are located.

The first two kinds of companies tend to be remote from the consumer, although some large companies like GE have both military and consumer divisions. The major companies of the third kind are in mining and oil. To follow the example of the NDG campaign, the leverage of retail companies might be required to influence other companies down the supply chain.

Companies that merely buy from developing countries or simply own or lease farmland are less likely nowadays than an extractive industry to be heavily invested in a single country. The production of bananas, for example, is now spread out over so many countries, and is so closely watched by consumers and politicians in developed countries, that today's banana wars are primarily about quotas and standards.

The difference between agriculture and the extractive industries is that agriculture needs only a favorable climate and land, and small-scale production is possible. Manufacturing is even more mobile. The extractive industries are players in issues of war and peace because they are tied to the mineral resources of a region.

Historically, large corporations in developing countries have contributed to a climate for civil and international wars by collaborating with repressive regimes. For example, corporations in the extractive industries have provided huge financial support to repressive dictatorships and have hired security guards from the military establishments of such regimes.

Attempts have been made to identify the root causes of recent conflicts and to assess the influence of commercial interests. The U.S. State Department under 
President Clinton drafted a report on the problem of persuading companies in the extractive industries to respect human rights and contribute to, rather than be an obstacle to, peacekeeping in developing countries.

\section{What economists can contribute}

Economists have something to offer NGOs. They can provide (a) guidance on strategy based on economic trends; (b) assistance in identifying possible negative outcomes and avoiding them; (c) guidance to donors seeking best use of their resources to sustain the planet; and (d) assistance to effective NGOs in making their case to donors. Economists can analyze the costs and benefits of potential and actual campaigns, the impact of campaigns, and their outcomes. Environmental economists have been working in this capacity at several NGOs. This type of analysis, applied to NGO activities, needs to be injected into business and economics courses and into the training of activists and corporate managers.

Focus on outcomes, not just victories

One danger of campaigning without regular attention to outcomes is that a campaign will be driven to "win" battles with corporations regardless of their impact on society. In this case, the outputs may look good, but the outcomes may be regrettable.

\section{Avoid lose-lose or even win-lose outcomes}

An extreme case of a lose-lose outcome is one where a company opposed to unionization of any of its facilities is persuaded by an NGO campaign to recognize a union and rehire any workers fired for organizing. This at first appears to be a win for labor and a loss for the company - but then the company decides to shut down the plant, store, or farm. The outcome is a pyrrhic victory, because workers lose jobs, the community economy sustains a substantial blow, and the company presumably loses market share and profit.

This kind of thing has happened several times in recent years. For example, an NGO launches a workers' rights campaign against a brand and convinces the brand to put pressure on supplier factories to improve standards. The factory works hard to meet these standards, but the brand does not place any more orders. This is a win-lose situation, as workers are laid off. Or a factory is pressured by a brand to recognize a union but then the owners/managers shut the factory down, to reopen in another location where the organizers are weaker. Again, an apparent win, but a negative outcome. When a Wal-Mart retail store in Canada was successfully organized, it was then closed down by Wal-Mart. This decision is consistent with past Wal-Mart behavior relative to unions. It appears to have been another poor outcome following a victory, but might be the basis of a larger battle with WalMart in Canada.

Win-win outcomes: cost-benefit analysis

From society's perspective, the optimum outcome would be one where the campaign wins by convincing a corporate or industry target to cooperate, and an agreement is put in place that satisfies both sides, including the other interested stakeholders.

Campaigns can influence companies more easily and sustainably by showing ways that the desired action could benefit the company. In general, stricter standards mean a larger gap between a typical company's practices and the level of performance required by the standard. A larger gap, in turn, implies higher costs for coming into compliance. Typically factory managers resist working toward higher environmental or labor standards because of a fear of higher costs. Yet an economist can measure benefits and use a capital budgeting model to show that an investment in complying with higher standards can pay for itself over time by bringing the benefits of:

$<$ Greater acceptability of suppliers to vendors, and therefore more orders.

$<$ Improved reputation.

$<$ Lowered risk of accidents and therefore reduced insurance premiums.

$<$ Greater factory/farm system efficiency.

$<$ Greater worker productivity.

$<$ Improvement in product quality.

$<$ Better employee health, lower employer health costs, and

$<$ Reduced employee turnover and absenteeism.

In a situation where the benefits pay for the cost of compliance over a short period, businesses will replicate the experiment on their own, making this a scalable and sustainable strategy. The NGO is a catalyst for change with momentum.

\section{Ideas for economists}

The Association to Advance Collegiate Schools of Business, which accredits business schools, has created a new program - "Peace through Commerce" - to encourage business schools to promote peace. ${ }^{16}$ The belief that commerce and peace are mutually reinforcing was an idea advanced by British utilitarians and by Immanuel Kant. It was part of the rationale for the United Nations and the European Union - countries that trade tend not to go to war. The University of 
Notre Dame, George Washington University, the University of Southern California, and Case Western Reserve University are planning conferences on peace through commerce in 2006. The Notre Dame conference planned for November 2006 has the support of the United Nations Global Compact Office, and U.N. Secretary-General Kofi Annan is scheduled as keynote speaker.

The world's foremost business school accreditation agency now sports a

"Peace through Commerce” program.

A book to be published in September 2006 argues that the U.N. has fallen short on its peacekeeping and development goals because of inadequate support for it by corporations.

The book's author, Michael Hopkins, argues that corporate social responsibility in this area could have "prevented the Iraq war." He says: "The relations between Halliburton, Bechtel, Carlyle and many other corporations in a CSR world would have been intensively examined ... [S]ocially irresponsible actions such as supporting war efforts for personal gain would have been stamped out."17

The NDG campaign suggests a number of possibly fruitful avenues of study and action for economists interested in the connections between civil conflict and multinational corporations. First, consumer prices that have risen rapidly create a climate for campaigns around industries in which they are rising. For peace activists, wars are a credible explanation of higher oil prices. Oil is presently an essential product, but a campaign might be built around a particular brand. Second, consumers are responsive to campaigns that bring issues of morality to the marketplace. They are willing to modify their buying patterns if certain brands are associated with corporate behavior of which they disapprove and there are options. Are there industries or companies that appear to be contributing to or benefitting from wars? Is there a brand that could be singled out for a corporate campaign? Third, to launch an NDG-like campaign for peace, one would need to identify alternative brands or products to companies that do not sign on. If a campaign targets the entire oil industry, for example, it could focus on ethanol and other alternative energy sources as a way of bringing peace. This is one of the ways that Petrobras has justified Brazil's heavy and successful investment in what it calls "sugar alcohol" as a fuel for its cars. An alternative-fuels campaign might demonstrate how localities can encourage ethanol use.

A growing number of mechanisms are in place to monitor actual corporate practices and provide rewards to responsive corporations and industries, while maintaining pressure on the brands to require environmental and workplace standards from their suppliers. But a link is missing between accepted multistakeholder global standards for corporate environmental and social responsibility and the issue of global prevention and resolution of conflicts. This link could be made as follows:
$<$ Environmental standards like those of the Forest Stewardship Council are multi-stakeholder agreements about proper respect for land by corporations. Labor standards like SA 8000 are multi-stakeholder agreements about proper respect for workers by corporations. A multi-stakeholder standard for peace would build in respect for people who are minorities in a divided country.

$<$ Processes and techniques for coming to multi-stakeholder agreements have been developed by the Search for Common Ground, essentially based on communication and mutual understanding and respect.

$<$ Because of the way that the standards are put together, the outcomes of these multi-stakeholder standards are likely to contribute to peaceful resolutions of conflicts. It is a matter for factual determination whether this is in fact the case.

$<$ A new standard could be developed for a corporate program to train employees in developing countries in conflict prevention and resolution.

These are issues requiring both analysis and organization. It would be useful to review the outcomes of past campaigns (mining, small arms, landmines, sweatshops, agriculture, and so on) to generate an objective assessment of their successes and failures, then analyze the characteristics of the more successful and less successful campaigns. It would also be helpful to consider the applicability of such a campaign to the avoidance of war. Such a campaign was successfully undertaken in the early 1970s by Another Mother for Peace against several consumer product companies that made parts for anti-personnel weapons.

\section{Conclusions and recommendations}

The NDG campaign has had rapid successes in bring jewelry retailers on board, suggesting that Oxfam America and Earthworks have tapped into a mother lode of influence by appealing to companies that depend on consumers. This article offers two main conclusions. First, a corporate campaign is likely to be more successful if a target industry or company has valuable brand names to protect and sells a nonessential product in a marketplace where alternatives are available. Second, economists can contribute to the success of such a campaign by using their analytical tools to raise the media profile of a corporate campaign, to reach large numbers of consumers, and to work effectively with corporations that are responsive to the issues raised in the campaign.

Can such a corporate campaign be conducted on behalf of peace? World peace through commerce is not a new slogan, but it is a timely one. Economists could support such a campaign by showing where U.S. foreign and military policies in the last few years have not been in the interest of most corporations or consumers. Economists might also suggest how a large private capital fund for world peace could be targeted. 
Notes

John Tepper Marlin is Principal of CityEconomist (www.cityeconomist.com). From 1992 to January 2006 he was Chief Economist for three elected New York City Comptrollers and, concurrently, Treasurer of Economists for Peace and Security (www.epsusa.org). He is Adjunct Professor of Business Ethics at New York University's Stern School of Business and Adjunct Professor of Finance and Economics at Pace University's Lubin School of Business. He thanks Jurgen Brauer for helpful comments.

1. See www.nodirtygold.org, www.oxfamamerica.org, and www.earthworksaction.org [accessed 11 June 2006].

2. Johnson (2006)

3. See www.responsiblejewellery.com [accessed 12 June 2006].

4. See www.phrusa.org [accessed 12 June 2006].

5. On "blood" diamonds and the Kimberly Process, see Gold (2006), in volume 1, no. 1 of this journal [www.epsjournal.org.uk].

6. Rainforest Alliance: see www.ra.org [accessed 14 June 2006].

7. See www.gapinc.com [accessed 14 June 2006].

8. See www.sa8000.org [accessed 14 June 2006]

9. See www.gold.org [accessed 10 June 2006].

10. For Freeport McMoRan, see www.fcx.com [accessed 14 June 2006].

11. See www.comptroller.nyc.gov [accessed 14 June 2006].

12. See www.riotinto.com [accessed 14 June 2006].

13. See www.responsiblejewellery.org [accessed 10 June 2006].

14. An exception was Economists for Peace and Security (www.epsusa.org) [accessed 14 June 2006].

15. Friedman and Sapolsky (2006).

16. See www.aacsb.org [accessed 12 June 2006]. Also see Wessel (2006).

17. Hopkins (2006).

\section{References}

Friedman, Benjamin H. and Harvey M. Sapolsky. 2006. "You Never Know(ism).”Breakthroughs (MIT Security Studies Program), Vol. XV, No. 1, pp. 3-4.

Gold, David. 2006. “The Attempt to Regulate Conflict Diamonds.” The Economics of Peace and Security Journal. Vol. 1, No. 1, pp. 49-52. [www.epsjournal.org.uk]

Hopkins, Michael. 2006. “Monthly Features.” April 2006. www.mhcinternational.com [accessed 1 June 2006]. Hopkins’ book Corporate Social Responsibility and International Development: Are Corporations The Solution? is scheduled to be published in September 2006 by Earthscan.

Johnson, Kirk. 2006. "With this Ethical Ring I Thee Wed.” New York Times, 6 April 2006. A link to this article appears on the NDG home page at www.nodirtygold.org [accessed 11 June 2006].

Wessel, Rhea. 2006. "Business Schools' New Mission: Promoting Peace: Programs Explore Ways Commerce Can Advance Society.” The Wall Street Journal. 2 June 2006. 